\title{
木造校舎における内装仕上材料 SURVEY ON THE COLOR の色彩特性に関する実態調査 PROPERTIES OF THE INTERIOR FINISHING MATERIALS OF THE WOODEN SCHOOLS
}

\section{土屋 潤——1 木村彰孝— $* 2$ \\ 川鍋亜衣子—* $* 3$ 飯島泰男—— \\ キーワード : \\ 木造学校，内装仕上材料，色彩特性，経年変化，補修}

Keywords:

Wooden school, Interior finishing materials, Color property, Aging, Repair

\section{Jun TSUCHIYA $-* 1$ \\ Akitaka KIMURA — $* 2$ \\ Aiko KAWANABE — $* 3 \quad$ Yasuo IIJIMA — $* 4$}

Color properties of interior finishing materials on the wooden schools in Noshiro, Akita were surveyed. Colorimeter was used for the measurement of material surface color and color values $\mathrm{L}^{*}, \mathrm{a}^{*}, \mathrm{~b}^{*}$ of interior finishing of 7 wooden schools were cleared. According to the results of the survey, it was found that the value $L^{*}$ of walls becomes low and $\mathrm{a}^{*}, \mathrm{~b}^{*}$ becomes high with the duration of building use.

The value $\mathrm{L}^{*}$ of floor was low with surface deterioration in long period of building use.

\section{1. はじめに}

2010 年 5 月、「公共建築物等における木材の利用の促進に関寸る 法律」が成立した。これを契機に、木材の持つ親環境性、低環境負 荷性や天然素材としての利点を標榜した木造学校建設はさらに増加 すると考えられる ${ }^{11}$ 。今後は、木造校舎の増加と長期供用に伴い、 内外装仕上げに関して、長期的な使用を考慮した材料選定や、補修 等の適切なメンテナンスも課題となるであろう。

一方これまでに、木質の内外装材試料を用いた屋外暴露試験や、 耐光性試験が行われ、その劣化の様相が示されている ${ }^{2,3)}$ 。材料表 面の色彩の変化は劣化程度を表す指標であると共に、建築空間の印 象に及ぼす影響が大きい要素であるため、材料の変退色に関する多 くの調査研究が実施されてきた。しかし、実建築物における木質内 装仕上げの色彩の経年変化や劣化に関しては様々な要因が影響して おり、その傾向を予測することは難しい。さらに、実建築物の木質 内装仕上げの色彩の実態についての研究例も少ないのが現状である ため、それらの色彩特性を把握することは重要である。

本研究では、一地域内にあり竣工時期が異なる木造校舎に着目し、 教室の木質内装仕上材料に関して、築年数毎の色彩の実態を調査し、 長期供用を想定した、今後の材料選定やメンテナンスの基礎資料と することを目的とする。

\section{2. 調査概要}

\section{1 調查地域と対象学校}

調查地域の能代市は国内有数のスギ生産地であり秋田県の北部に

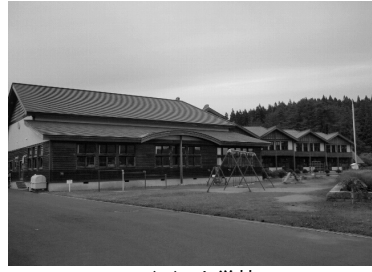

(A) 小学校

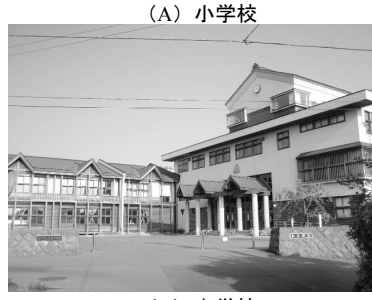

(C) 中学校

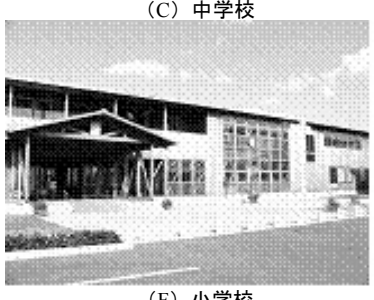

(F) 小学校

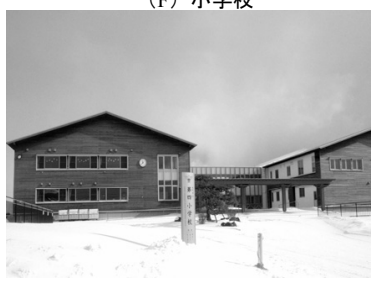

(H) 小学校

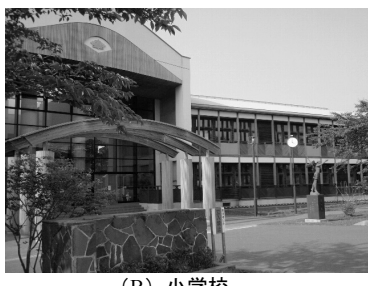

(B) 小学校

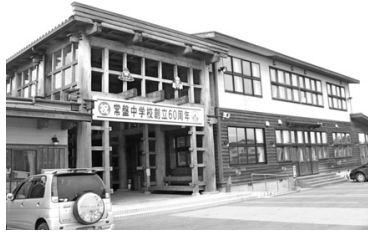

(DE) 小中学校

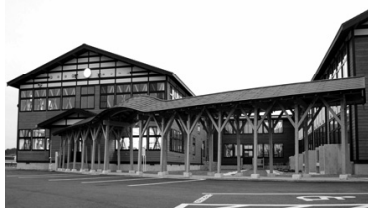

(G) 小学校

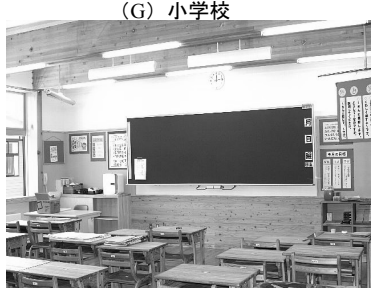

教室内部 (G 小学校)

写真 1 調査対象校の外観と教室内部の例

\footnotetext{
秋田県立大学木材高度加工研究所 流動研究員 ・博士 (工学) ( (016-0876 秋田県能代市字海詠坂 11-1)

京都大学生存圈研究所 ミッション専攻研究員・博士 (生物資源科学)

秋田県立大学木材高度加工研究所 准教授 ·博士（工学）

秋田県立大学木材高度加工研究所＼cjkstart教授・農博
}

Postdoctoral Researcher, Institute of Wood Technology, Akita Prefectural Univ., Dr. Eng.

Postdoctoral Fellow, Research Institute for Sustainable Humanosphere, Kyoto Univ., Ph. D.

Assoc. Prof., Institute of Wood Technology, Akita Prefectural Univ., Dr. Eng. Prof., Institute of Wood Technology, Akita Prefectural Univ., Dr. Agr. 
表 1 各校の概要

\begin{tabular}{|c|c|c|c|c|c|c|c|}
\hline \multirow{3}{*}{ 名称 } & \multirow{3}{*}{$\begin{array}{l}\text { 竣工年. 月 } \\
\text { (築年数*1) }\end{array}$} & \multirow{2}{*}{\multicolumn{2}{|c|}{ 構造 }} & \multicolumn{4}{|c|}{ 主要使用材料 } \\
\hline & & & & \multirow{2}{*}{ 構造材 } & \multicolumn{3}{|c|}{ 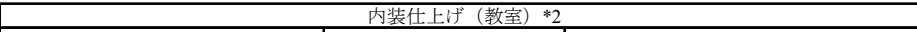 } \\
\hline & & 校舎 & 体育館 & & 床 & 腰壁 & 壁（木材以外） \\
\hline (A) 小学校 & $1995.3(14)$ & $\begin{array}{l}\text { 木造一部RC造 } \\
\text { 2階建 }\end{array}$ & S造平屋建 & スギ・ベイマツ & $\begin{array}{l}\text { フローリングブロック（直貼り）杉 } \\
\text { 表面熱厓処理UVセラミック塗装品 }\end{array}$ & $\begin{array}{l}\text { 秋田スギ板張り EP（無 } \\
\text { 色） }\end{array}$ & $\begin{array}{l}\text { 無石綿セメント珪酸カルシウム板, 吹き } \\
\text { 付けEP (白色) }\end{array}$ \\
\hline (B) 小学校 & $1995.11(14)$ & \begin{tabular}{|l} 
木造一部RC造 \\
2 階建
\end{tabular} & 木造平屋建、一部RC造 & スギ・ベイマツ & $\begin{array}{l}\text { スギ板張ブロック（12mm合板下地） } \\
\text { UVセラミック塗装品 }\end{array}$ & |スギ板張り EP(無色) & $\begin{array}{l}\text { ジョイント石亳ボード+クロス貼,ラワン } \\
\text { 合板+掲示用クロス貼（白色） }\end{array}$ \\
\hline (C) 中学校 & $2000.12(10)$ & \begin{tabular}{|l} 
木造一部RC造 \\
2 2階一部3階建
\end{tabular} & 木造平屋建、一部RC造 & スギ・ベイマツ & $\begin{array}{l}\text { フローリングブロック（針葉樹合板 } \\
\text { 下地）、塗装有 }\end{array}$ & スギ板縦張り EP（無色） & 硬質石膏ボードEP \\
\hline (DE) 小中学校 & $2004.3(6)$ & $\begin{array}{l}\text { 木造一部RC造 } \\
\text { 2階一部3階建 }\end{array}$ & 木造平屋建、一部RC造 & スギ・ベイマツ & $\begin{array}{l}\text { フローリングブロック（針葉樹合板 } \\
\text { 下地）、塗装有 }\end{array}$ & $\begin{array}{l}\text { スギ板縦張りEP (無 } \\
\text { 色)、( (石膏ボード下地) }\end{array}$ & 石膏ボードEP \\
\hline (F) 小学校 & 2006.3 & 木造2階建 & 木造平屋建、一部RC造 & スギ・ベイマツ & 単層フローリング（ブナ）、塗装有 & シナ合板EP（無色） & シナ合板内装パネル,珪藻土薄塗（白色） \\
\hline (G) 小学校 & $2010.3(0.5)$ & $\begin{array}{l}\text { 木造一部RC造 } \\
2 \text { 階建 }\end{array}$ & 木造平屋建、一部RC造 & スギ・ベイマツ & $\begin{array}{l}\text { 複合フローリング（根太レス合 } \\
\text { 板）、塗装有 }\end{array}$ & スギ板横張り EP（無色） & 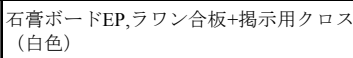 \\
\hline (H) 小学校 & $2010.3(0.5)$ & $\begin{array}{l}\text { 木造一部RC造 } \\
2 \text { 2階建 }\end{array}$ & 木造平屋建、一部RC造 & スギ・ベイマツ & $\begin{array}{l}\text { 複合フローリング（根太レス合 } \\
\text { 板）、塗装有 }\end{array}$ & スギ貼柾合板EP (無色) & 掲示用クロスEP（白色） \\
\hline
\end{tabular}

*1 測定時点 *2 EP ; エマルションペイント塗り

\section{表 2 測定部位の概要}

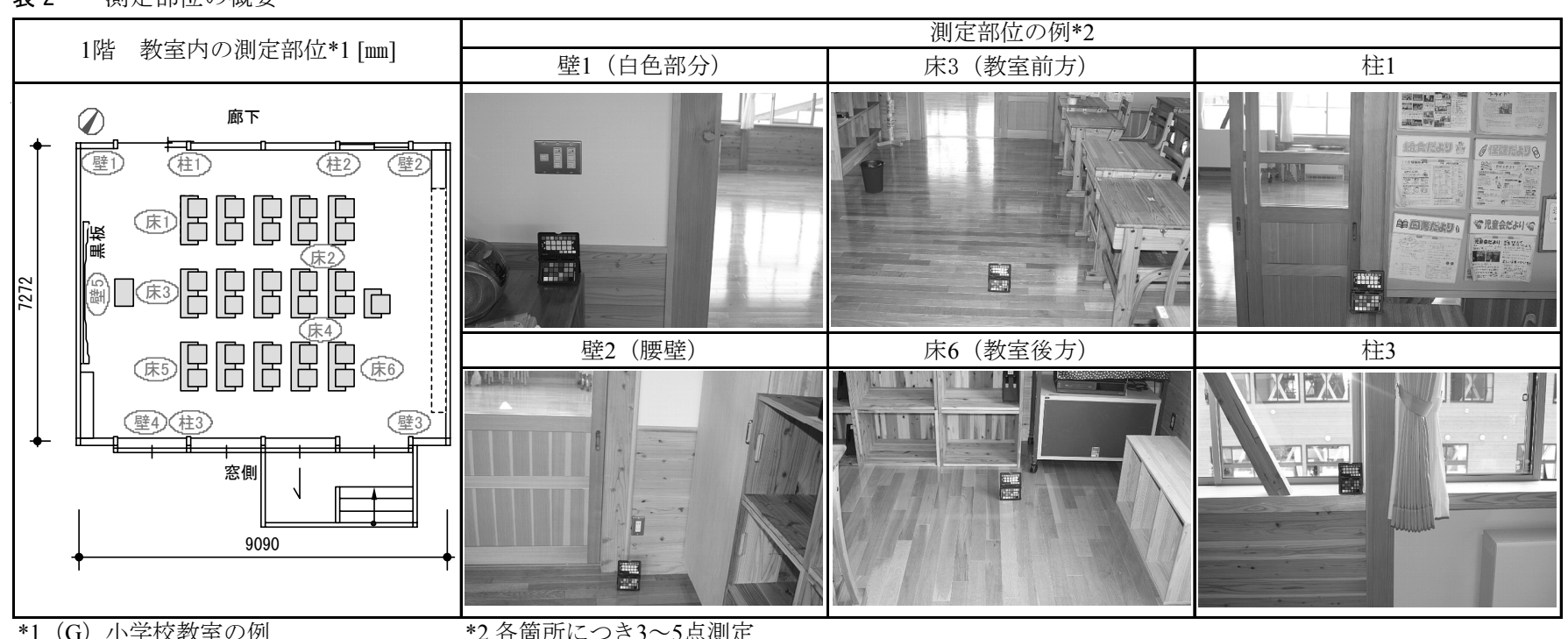

1（G）小学校教室の例

$* 2$ 各箇所につき $3 \sim 5$ 点測定

位置する。能代市では 1994 年以降、市立の小中学校の建設（改築お よび新築）にあたり、構造を木造とするという施策が講じられてき た。市立の学校数 20 校のうち 7 校舎 (1 校は小中学校の併設のため、 学校数は 8) で木造化が実施された（2010 年 8 月現在） ${ }^{4)}$ 。

調查対象は、これらの木造学校 7 校 $(\mathrm{A}) \sim(\mathrm{H})$ で、調查は 2010 年 8 月〜 10 月に実施した。写真 1 に各校の外観と、表 1 に各校の設計図 書の情報を基にした概要を示す。

各校は、調查時の築年数が最も長い 14 年の（A）小学校から、築 年数半年の $(\mathrm{G}) 、(\mathrm{H})$ 小学校で、規模等は異なるが、木造で、地域 の設計者、木材関連企業、建設業者が係り、内装仕上げにも木材が 多用されているのが特徵である。

\section{2 内装仕上材料の色彩測定方法}

内装仕上材の測定は、校舎内の教室・廊下・玄関ホール・階段等 で行ったが、本研究では各校とも仕様や採光の条件がほぼ同様で、 部位別に比較し易い、普通教室を選定し分析に用いることとした。 測定対象は基本的には木材とし、比較のため壁にクロス貼・EP 塗装 等が施された白色部分を含めた。

測定部位は教室内の、壁 5 箇所、柱 3 箇所（壁と柱は、床上 1000 $\sim 1300 \mathrm{~mm}$ の付近)、床 6 箇所とし、表面の $100 \mathrm{~mm}$ 角範囲で色調がほ ぼ均一と判断される部分を目視観察により特定し、3〜 5 点の色彩值
表 3 内装仕上材料の色彩に影響を及ぼす劣化の事例

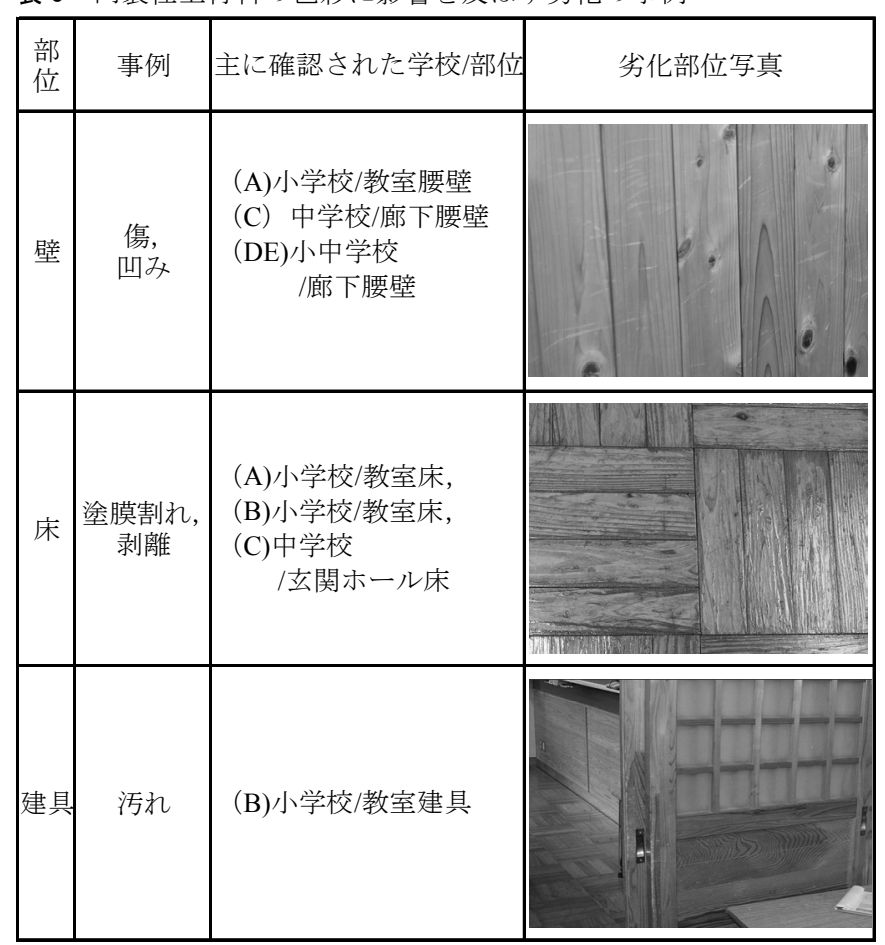


L* a*、b*を測定し平均化した。測定機は、接触式の分光測色計 （BKY-Gardner Color-guide45/0）を用い、測定条件は、D65 光源、10 視野、測定径 $20 \mathrm{~mm}$ であった。ここで、L*は明度を表し、a*と b*で 表示される色度図上の值は、マンセル表色系における色相（色味） と彩度（色味の強さ）を合わせた概念に対応する。

表 2 に測定部位の概要を示す。同表は $(G)$ 小学校の場合を示す が、1 階で北や北西側に廊下、南や南東側に空を配した平面は各校 とも共通で、細部は異なる箇所もあったが、教室内の相対的位置が 同様となるように、（A）〜（H）小・中学校内も同様に測定した。

各校の教室内部の清掃に関しては、調查時においては、床はほう きを使用した掃き掃除やモップ掛け（乾拭き）を基本とし、半年〜 1 年に一回程度のワックス掛けを行っていた。壁と柱は通常は特に清 掃は行っていなかった。

\section{3 内装仕上材料の色彩に影響を及ぼす劣化の事例}

色彩の測定時には、同時に内装仕上材料の劣化状況を目視により 確認した。これらは、材料表面の一部で著しい明度・彩度低下等の 要因となると予想される。

表 3 に、確認された主な劣化事例を示す。腰壁部分には、教室の 使用状況によっても異なるが、傷や凹みが見られた。床に関しては、 築年数の長い、(A) ・ (B) 小学校で、表面の塗膜割れと剥離が多く 確認された。教室内の場所によりその程度も異なり、特に教室内の 中央・前方の床 3 や空側・後方の床 6 （表 2) においては曊著に見ら れた。学校により、劣化の激しい部位を張り替えた補修箇所も見ら れた。また手が接触する壁や柱、建具に見られる事例で、(B) 小学 校等の教室入口引き戸の取っ手周辺に、手垢と思われる污れが見ら れた。

\section{3. 結果及び考察}

3.1 各学校内装仕上材料の部位別の色彩の測定結果

図 1 に各校築年数毎の教室内の壁の色彩值 $\mathrm{L}^{*} 、 \mathrm{a}^{*} 、 \mathrm{~b}$ *を、同様に 図 2 に柱の色彩值、図 3 に床の色彩值を示す。図中の部位 1 5 は表 2 の教室内の測定部位に対応寸る。なお、各校の測定部位は異なる 材料もあるが、本研究では各校の築年数に対して色彩值のデータを 整理した。

（1）壁 1 の色彩值 $\mathrm{L}^{*}, \mathrm{a}^{*}, \mathrm{~b}^{*}$

壁 1 は、木材以外の白色部分であり、(C) 中学校、(DE) 小中学 校に関しては、有彩色の塗装が施されていたため分析から除外し 5 件のデータを示す。各校とも白色部分は、石膏ボード等に塗装が施 される仕様であった。

L*值は、築年数に伴いやや減少寸る傾向が見られた。これは、竣 工直後の高明度の白色が、光や污れにより明度低下寸るためと考え られるが、塗材の性能にも影響を受けると推察される。(F) 小学校 は竣工後 4 年経過しているが、壁 1 の L*は高い值であった。

$\mathrm{b}$ *值は築年数に伴い、増加傾向にあった。b*はマイナスが青方向、 プラスが黄方向を表すことから、やや黄味が増すことがわかる。

a*值は、各校ともほぼ同様の值を示した。a*はマイナスが緑方向、 プラスが赤方向を表している。木材以外の白色部分に関しては、築 年数に伴う $\mathrm{a}$ *值の変化が少ないと考えられる。

（2）壁 2〜壁 5 の色彩值 $\mathrm{L}^{*}, \mathrm{a}^{*}, \mathrm{~b}^{*}$

壁 2〜壁 5 は、各校の腰壁で木材部分であり、築年数 4 年の（F)
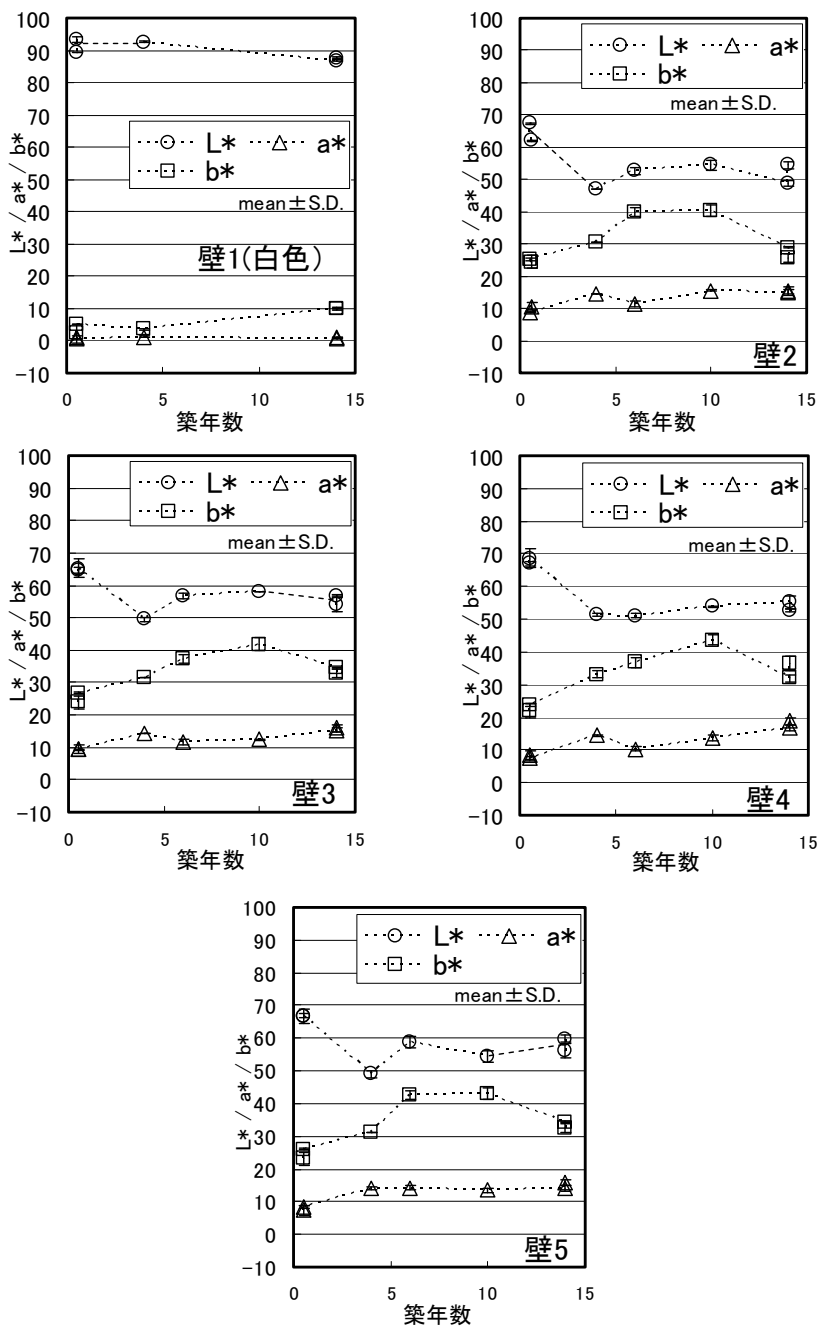

図 1 各校教室内の壁の色彩值 $\mathrm{L}^{*}, \mathrm{a}^{*}, \mathrm{~b}^{*}$
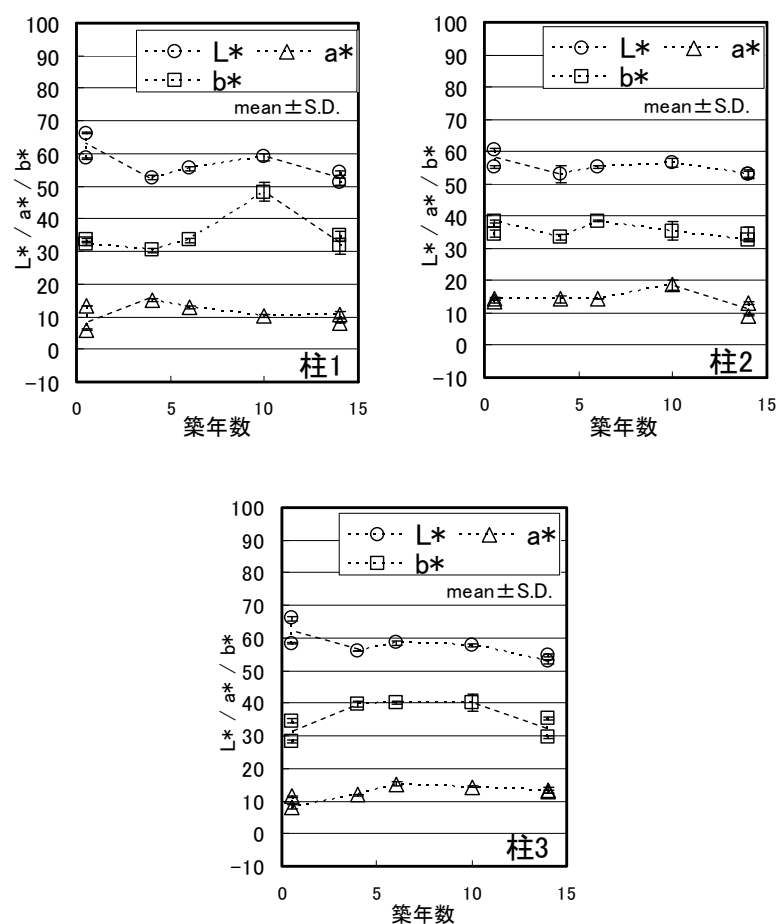

図 2 各校教室内の柱の色彩值 $\mathrm{L}^{*}, \mathrm{a}^{*}, \mathrm{~b}^{*}$ 
小学校以外はスギを用いている。（F）小学校の場合、シナ合板を使 用しているため、 $\mathrm{L}^{*}$ 值が他校よりも低い傾向が壁 2〜壁 5 とも同様 に見られた。

全体的に $\mathrm{L}^{*}$ 值は、築年数に伴い、 $+70 \sim+50$ の範囲で減少する 傾向が見られ、各壁とも同様の傾向であった。

a*值は築年数が長いものほど増加する傾向が見られ、赤味が増す と考えられる。

$\mathrm{b} *$ 值は、築年数 6 年の (DE) 小中学校と 10 年の $(\mathrm{C})$ 小学校の值 が高く黄味が強く、築年数に伴い増加寸る傾向が見られたが、築年 数 14 年の（A）、（B）小学校については值が低かった。

(3) 柱の色彩值 $\mathrm{L}^{*}, \mathrm{a}^{*}, \mathrm{~b}^{*}$

柱は、教室内で現しとなっている箇所で、柱 1 、柱 2 が廊下側で 柱 3 を空側とした。

$L^{*}$ *值に関しては、築年数に伴い、減少の傾向が見られたが、柱 1 、 柱 3 で築半年の $(\mathrm{G})$ 小学校の值が高かった。

$\mathrm{a}$ *值、 $\mathrm{b}$ *值に関しては、柱 1 3 において、（G）小学校の值が低 く、柱 1 の $\mathrm{b} *$ 值で築 10 年の (C) 中学校が高い結果だったが、各校 とも築年数との明確な関係が見られなかった。

（4）床の色彩值 $\mathrm{L}^{*}, \mathrm{a}^{*}, \mathrm{~b}^{*}$

床は、校舎により使用材料が数種にわたり異なるため、初期の色 彩值にはばらつきがあると考えられるが、築年数が長いものほど、 目視により劣化が多く確認され、明度低下が見られた。

L*值に関しては、築年数に伴い減少する傾向が見られた。教室中 央で前方の床 3 と、空側で後方の床 6 における明度低下が確認され たが、築年数に伴う $\mathrm{L} *$ 值の減少は劣化（塗膜割れ）による影響であ ると考えられる。

$\mathrm{a}^{*}$ 值は、築年数が長いものほどやや増加の傾向が見られ、赤味が 増すといえる。

$\mathrm{b}$ *值は、床 1 、床 2 で築年数に伴い増加の傾向がみられたが、床 $3 、$ 床 4、床 5、床 6 で築年数に伴う明確な傾向が見られなかった。

\section{4.まとめ}

秋田県能代市の築半年から 14 年の木造校舎を対象に、教室の木質 内装仕上材料の色彩特性に関する実態調査をし、分析を行った。以 下に得られた知見を示す。

1）教室内の壁（木材以外の白色部分）に関しては、築年数に伴い $\mathrm{L} *$ 值は減少し明度が低下し、 $b^{*}$ 值は増加し黄味が増す傾向が見 られた。

2）教室内の壁（木材・腰壁部分）に関しては、築年数に伴い $\mathrm{L}^{*}$ 值は減少し、 $a$ *值、 $b$ *值は増加寸る傾向が見られた。

3）柱に関しては、築年数に伴い $L$ *值がやや減少する傾向がある が、a*值、 b*值は築年数との明確な関係は見られなかった。

4）床に関しては、塗膜割れ等の劣化が影響し、 $L *$ 值が減少して いる箇所が見られた。特に教室内の中央前方と空側後方にその 傾向が顕著であった。

【謝辞】資料収集にあたり能代市教育委員会にご協力いただきまし た。また調查時には、各学校関係者にご協力いただきましたことを ここに御礼申し上げます。
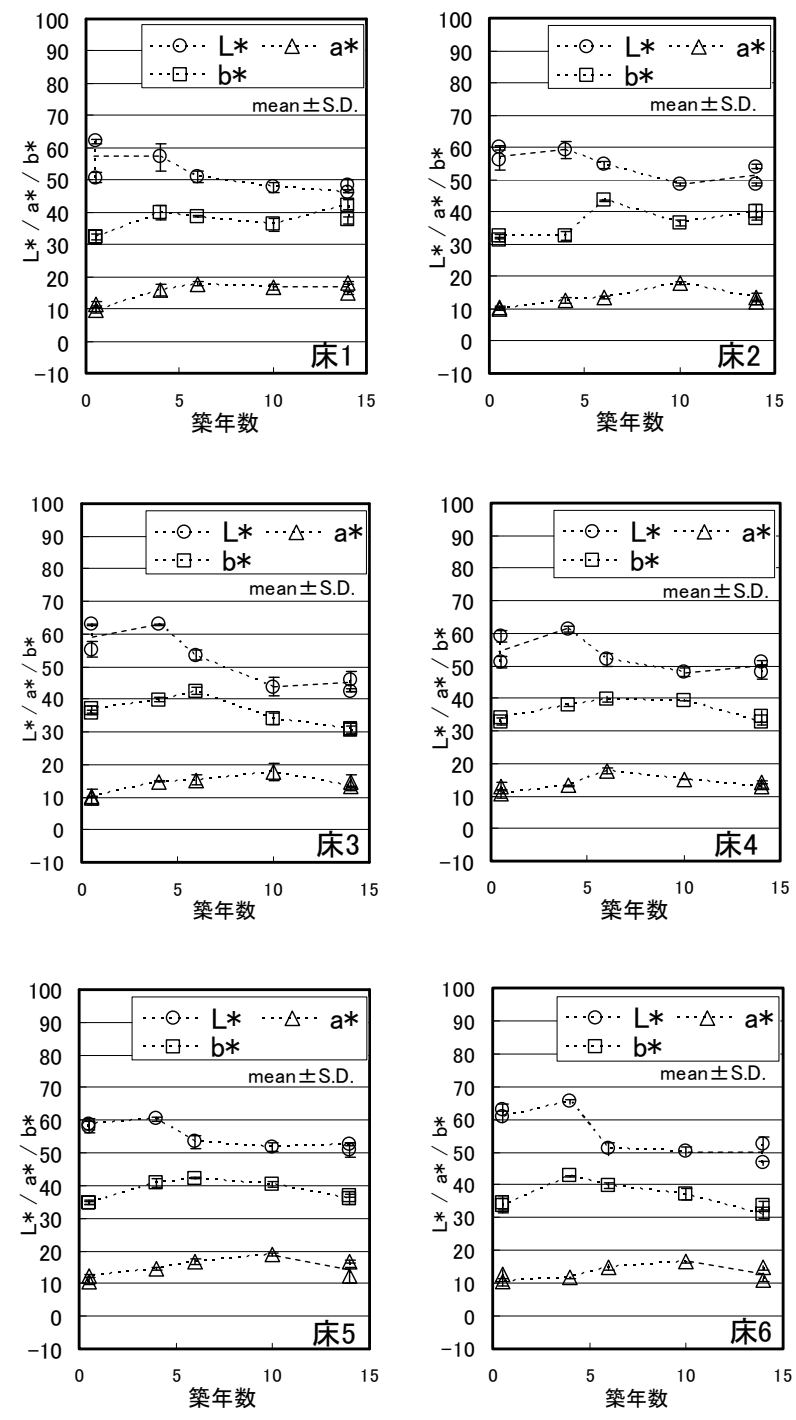

図 3 各校教室内の床の色彩值 $\mathrm{L}^{*}, \mathrm{a}^{*}, \mathrm{~b}^{*}$

\section{参考文献}

1)文部科学省 農林水産省 : こうやってつくる 木の学校〜木材利用の進め 方のポイント、工夫事例〜 2010

2)本橋健司, 大島明 : 木材保護塗料の耐久性評価, 日本建築学会構造系論文 集 No.588,pp.35-42, 2005.2

3) 辻本吉寛, 今村祐嗣：内装材料の耐光性評価方法の開発（第 2 報）新規耐 光試験方法の木質内装材料への適用, 木材学会誌 Vol.53, No.3, pp.141-148, 2007

4) 土屋潤, 川鍋亜衣子, 飯島泰男, 松田昌洋, 浦江真人, 秋山哲一: 秋田県 能代市における木造学校建設事例の検証, 日本建築学会第 26 回建築生産シン ポジウム論文集, pp.115-120, 2010.7

5) 橘高義典, 田村雅紀, 佐藤昭夫, 松山祐子, 土屋潤 : 多摩ニュータウン地 域の集合住宅の外装材料の色彩特性に関する実態調査, 日本建築学会技術報 告集 No.21, pp.45-49, 2005.6

6)JIS Z8729:2004 色の表示方法-L*a*b*表色系及び L*u*v*表色系

[2011 年 6 月 20 日原稿受理 2011 年 9 月 6 日採用決定］ 